\title{
KONSTRUKSI MAKNA PERKAWINAN CAMPURAN BAGI PEREMPUAN MUSLIM INDONESIA
}

\author{
Zikri Fachrul Nurhadi ${ }^{1}$, Sheila Yandini ${ }^{2}$ \\ ${ }^{1,2}$ Fakultas Ilmu Komunikasi, Konsentrasi Public Relations, Universitas Garut \\ Jl. Cimanuk No. 285A Tarogong Kidul, Garut 44151 \\ No. Telp./HP: ${ }^{1} 085353325544,{ }^{2} 089619215152$ \\ E-mail: ${ }^{1}$ kiky_81@yahoo.co.id, ${ }^{2}$ sheila_yandini@yahoo.com
}

Naskah dikirim tanggal 1 Februari 2016, direvisi tanggal 11 April 2016, diterima tanggal 12 April 2016

\section{CONSTRUCTION MEANING OF MIXED MARRIAGES FOR INDONESIAN MUSLIM WOMEN}

\begin{abstract}
The background of this problem is the increasing number of Indonesian citizens who perform mixed marriages, especially women who are married to foreign nationals. This, resulted in the problem starts from differences of religion or belief, culture and lifestyle are different. The purpose of this study is to find and explain the motives, meaning and experience of Indonesian Muslim women as perpetrators of intermarriage. This research method using the phenomenological method that focuses on the study of meaning in everyday life from the perspective of those who experience it. Data collection techniques used participant observation, interview and documentation study. Subjects were Indonesian Muslim women aged 30-40 years, were married to foreign nationals by purposive sampling technique. The results showed that mixed marriages have a motive "because" that is the motive trauma and interest, while the motive "for" consists of the dream motive, worship and repair descent. Likewise intermarriage experience demonstrated mutual culturally adjust, adapt to a multicultural, open and romantic attitude. While the meaning of marriage is an interesting mix, happy, merging two cultures, respect for differences, mutual understanding, complex, beautiful. Construction of meaning formed that a mixed marriage is a marriage of attractive, beautiful, full of challenges in the face of differences in terms of culture, habits and mindset in running family life.
\end{abstract}

Keywords: construction meaning, mixed marriage, phenomenology, indonesian muslim women, foreign nationals.

\begin{abstract}
Abstrak. Latar belakang masalah penelitian ini adalah semakin banyaknya Warga Negara Indonesia (WNI) yang melakukan perkawinan campuran terutama kaum perempuan yang menikah dengan Warga Negara Asing (WNA). Hal ini, mengakibatkan terjadinya masalah dimulai dari perbedaan agama atau keyakinan, budaya serta pola hidup yang berbeda. Tujuan penelitian ini adalah untuk menemukan dan menjelaskan motif, makna dan pengalaman perempuan muslim Indonesia sebagai pelaku perkawinan campuran. Metode penelitian ini menggunakan metode fenomenologi yang berfokus pada kajian pemaknaan pada kehidupan sehari-hari dari sudut pandang orang yang mengalaminya. Teknik pengumpulan data yang digunakan observasi partisipan, wawancara mendalam, dan studi dokumentasi. Subjek penelitian adalah perempuan muslim Indonesia berusia 30-40 tahun yang menikah dengan Warga Negara Asing (WNA) dengan teknik purposive sampling. Hasil penelitian menunjukkan bahwa perkawinan campuran memiliki motif "karena" yaitu motif trauma dan
\end{abstract}


ketertarikan, sedangkan motif "untuk" terdiri dari motif impian, beribadah, dan memperbaiki keturunan. Begitupun pengalaman perkawinan campuran menunjukkan saling menyesuaikan budaya, beradaptasi multikultural, sikap terbuka dan romantis. Sedangkan makna perkawinan campuran ini adalah menarik, bahagia, penggabungan dua budaya, menghargai perbedaan, saling pengertian, kompleks, indah. Konstruksi makna yang terbentuk bahwa perkawinan campuran adalah perkawinan yang menarik, indah, penuh tantangan dalam menghadapi perbedaan dari sisi kebudayaan, kebiasaan dan pola pikir dalam menjalankan kehidupan berkeluarga.

Kata kunci: konstruksi makna, perkawinan campuran, fenomenologi, perempuan muslim Indonesia, WNA.

\section{PENDAHULUAN}

Perkawinan campuran adalah salah satu hal yang fenomenal khususnya di Indonesia, sehingga hal ini menarik terutama bagi kalangan perempuan muslim di Indonesia untuk menjadikan realitas ini sebuah hal yang unik. Hal ini, mencerminkan bahwa perkawinan campuran yang dilakukan oleh perempuan muslim di Indonesia memiliki nilai yang tidak terlepas dari hal-hal yang bersifat positif maupun negatif.

Menurut UU No. 1 Tahun 1974 tentang Perkawinan, dalam Pasal 1 memuat pengertian bahwa perkawinan ialah ikatan lahir batin antara seorang pria dan seorang wanita sebagai suami istri dengan tujuan membentuk keluarga yang bahagia dan kekal berdasarkan Ketuhanan Yang Maha Esa (Republik Indonesia, 1974). Namun, ketika perkawinan dilakukan oleh Warga Negara Indonesia (WNI) dengan Warga Negara Asing (WNA) disebut sebagai perkawinan campuran. Sesuai dengan yang tercantum dalam pasal 57 UU Perkawinan, yang dimaksud dengan perkawinan campuran adalah perkawinan antara dua orang yang di Indonesia tunduk pada hukum yang berlainan, karena perbedaan kewarganegaraan dan salah satu pihak berkewarganegaraan Indonesia. Jadi, perkawinan seorang WNI dengan WNA merupakan perkawinan campuran.

Salah satu kendala yang sering terjadi dalam perkawinan campuran adalah perbedaan agama atau keyakinan. Sebab, setiap agama pasti menganjurkan umatnya menikah dengan orang yang seiman. Hal demikian, secara tidak langsung memaksa pelaku perkawinan campuran untuk membuat sebuah keputusan dalam hal memilih. Misalnya dengan salah satunya pindah agama mengikuti seseorang yang lainnya. Namun tidak jarang dari mereka memilih untuk konsisten dengan agama masing-masing dengan satu-satunya cara yaitu melangsungkan pernikahan di luar negeri.

Mayoritas WNI adalah muslim, dalam hukum Islam diwajibkan seorang muslim menikah dengan orang yang seagama, namun bisa dianggap dilema ketika seorang muslim ingin melakukan sebuah perkawinan campuran dengan WNA yang non muslim, tantangan bagi mereka untuk menikah dengan orang yang berbeda agama. Tidak menutup kemungkinan salah satu dari mereka harus pindah agama.

Perkawinan campuran memang menghadirkan suatu hal yang unik karena keduanya dapat bertukar kebudayaan yang berbeda. Banyaknya para ikon atau pelaku perkawinan campuran ini menciptakan sebuah pandangan yang berbeda-beda terhadap perkawinan campuran, bahkan beberapa masyarakat memandang bahwa perkawinan campuran adalah sudah menjadi popularitas bagi perempuan muslim Indonesia. Perkawinan campuran bukan hal yang mudah. Pertimbangan-pertimbangan dibutuhkan dalam berbagai hal karena lebih banyak perbedaan yang muncul dibandingkan dengan perkawinan sesama warga negara Indonesia. Apalagi perkawinan yang dilakukan oleh dua orang 
yang awalnya berbeda agama, penyesuaian bukan hanya dalam hal budaya, tetapi juga hal perbedaan pola hidup yang berbeda. Berdasarkan pemaparan yang telah dijelaskan, maka dapat ditarik beberapa permasalahan terkait dengan konstruksi makna perkawinan campuran bagi perempuan muslim Indonesia, yaitu bagaimana motif, pengalaman, dan makna perempuan muslim Indonesia pelaku perkawinan campuran yang menikah dengan WNA.

\section{LANDASAN KONSEP}

\section{Penelitian Terdahulu}

Sejumlah penelitian tentang konstruksi makna perkawinan campuran bagi perempuan muslim Indonesia yang menikah dengan WNA belum banyak dilakukan. Hal ini, dimaksudkan untuk memberikan bahan perbandingan dan referensi agar konstruksi makna yang terjadi dalam perkawinan campuran dapat dipahami, sehingga penelitian ini mampu menyajikan hasil penelitian yang memiliki nilai originalitas. Adapun penelitianpenelitian sebelumnya yang relevan dengan masalah yang diteliti dapat dilihat pada tabel 1 .

\section{Teori Konstruksi Sosial}

Istilah konstruksi sosial atas realitas (social construction of reality) didefinisikan sebagai proses sosial melalui tindakan dan interaksi yang diciptakan individu secara terus-menerus suatu realitas yang dimiliki dan dialami bersama secara subjektif. Berger mampu mengembangkan model teoretis lain mengenai bagaimana dunia sosial terbentuk. Dia menganggap realitas sosial eksis dengan sendirinya dan struktur dunia sosial bergantung pada manusia yang menjadi subjeknya (Poloma, 2000). Bersama dengan Thomas Luckmann, Berger menuangkan pikiran tentang konstruksi sosial dalam buku berjudul The Social Construction Reality. Berger dan
Luckmann dalam bukunya menyebutkan bahwa seseorang hidup dalam kehidupannya mengembangkan suatu perilaku yang repetitive, yang mereka sebut sebagai "kebiasaan" (habits) (Basrowi and Sukidin, 2002). Kebiasaan ini memungkinkan seseorang mengatasi suatu situasi secara otomatis. Kebiasaan seseorang ini berguna juga untuk orang lain. Dalam situasi komunikasi interpersonal, para partisipan ("aktor" menurut Schutz) saling mengamati dan merespon kebiasaan orang lain, dan dengan cara seperti ini semua partisipan dapat mengantisipasi dan menggantungkan diri pada kebiasaan orang lain tersebut (Suparno, 1997).

Berdasarkan teori Konstruksi Sosial maka fenomena konstruksi makna tentang perkawinan campuran perempuan muslim yang menikah dengan WNA merupakan realitas sosial yang eksis dengan sendirinya. Hal ini diciptakan oleh para pelaku yang melakukan perkawinan campuran untuk mengubah struktur kehidupan mereka yang saling memiliki ketergantungan untuk menciptakan dunia sosialnya sebagai makhluk yang bisa beradaptasi dengan lingkungan budaya bahkan agama yang berbeda.

\section{Teori Fenomenologi}

Fenomenologi mempelajari struktur pengalaman sadar (dari sudut pandang orang pertama), bersama dengan kondisikondisi yang relevan. Menurut Husser dalam Kuswarno (2009) dengan fenomenologi kita dapat mempelajari bentuk-bentuk pengalaman dari sudut pandang orang yang mengalaminya langsung, seolah-olah kita mengalaminya sendiri. Sedangkan inti pemikiran Schutz adalah bagaimana memahami tindakan sosial melalui penafsiran. Schutz meletakan hakikat manusia dalam pengalaman subjektif, terutama ketika mengambil tindakan dan mengambil sikap terhadap dunia kehidupan sehari-hari (Kuswarno, 2009). Adapun studi fenomenologi 
Tabel 1

Perbedaan Penelitian Konstruksi Makna Perkawinan Campuran Bagi Perempuan Muslim Indonesia dengan Penelitian Terdahulu

\section{Konstruksi Makna \\ Perkawinan Antar Negara \\ (Konstruksi Makna \\ Perkawinan Campuran \\ AntarNegara bagi Istri \\ Warga Negara Indonesia \\ yang telah menikah dengan \\ Suami yang berasal dari \\ Mesir)}

\author{
Konstruksi Makna \\ Kepedulian Sosial Oleh \\ Anggota Kelompok \\ Jatinangor 21 Melalui \\ Kegiatan Adik Asuh
}

\author{
Konstruksi Makna \\ Perkawinan Campuran Bagi \\ Perempuan Muslim Indonesia
}

\section{Feni Novida Saragih}

\section{Zikri Fachrul Nurhadi dan Sheila Yandini}

\begin{tabular}{|c|c|}
\hline Penulis & Ghia S. Anugrah \\
\hline $\begin{array}{l}\text { Deskripsi } \\
\text { Penelitian }\end{array}$ & $\begin{array}{l}\text { Deskripsi penelitian ini } \\
\text { berfokus pada bagaimana } \\
\text { seorang perempuan muslim } \\
\text { yang melakukan perkawinan } \\
\text { campuran memaknai } \\
\text { perkawinan campuran tersebut } \\
\text { berdasarkan pengetahuan dan } \\
\text { pengalamannya sendiri dalam } \\
\text { kehidupannya sehari-hari } \\
\text { sebagai pelaku perkawinan } \\
\text { campuran. }\end{array}$ \\
\hline
\end{tabular}

Fokus Penelitian
Fokus penelitian ini kepada perempuan muslim yang melakukan perkawinan campuran dengan suami yang berasal dari Mesir.

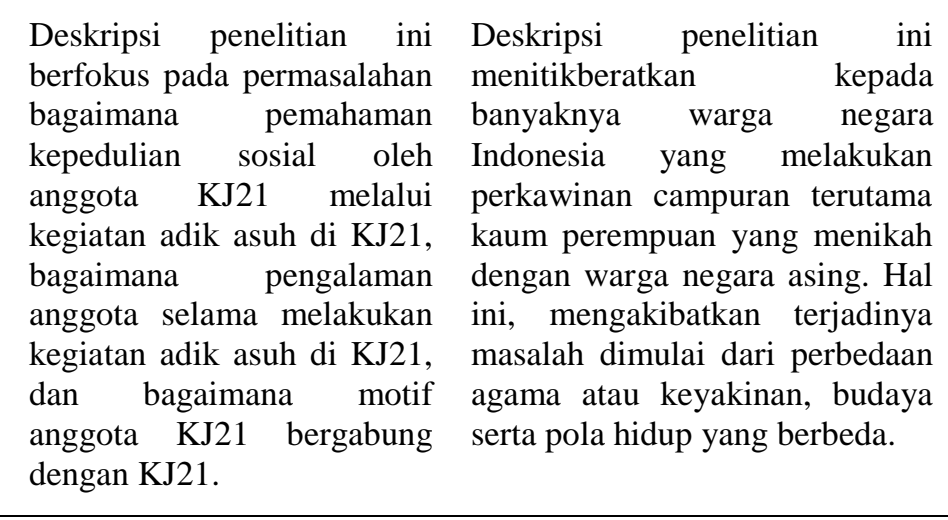

Fokus penelitian ini kepada anggota $\mathrm{KJ} 21$ yang diteliti dari aspek motif, pengalaman dan makna sebagai anggota KJ21.

\begin{tabular}{ll}
\hline Tujuan & Untuk mengetahui motif, \\
Penelitian & konstruksi makna "perkawinan \\
& campuran antar negara" dan \\
& pengalaman yang didapatkan \\
& dari para istri warga negara \\
& Indonesia yang menikah \\
& dengan suami dari negara \\
& Mesir.
\end{tabular}

Untuk mengetahui pemahaman kepedulian sosial oleh anggota KJ21 melalui kegiatan adik asuh di KJ21, mengetahui pengalaman anggota selama melakukan kegiatan adik asuh di KJ21, dan mengetahui motif anggota $\mathrm{KJ} 21$ bergabung dengan $\mathrm{KJ} 21$.

\begin{tabular}{|c|c|c|c|}
\hline $\begin{array}{l}\text { Pendekatan } \\
\text { Penelitian }\end{array}$ & Kualitatif & Kualitatif & Kualitatif \\
\hline $\begin{array}{l}\text { Teknik } \\
\text { Pengumpulan } \\
\text { Data }\end{array}$ & $\begin{array}{l}\text { Studi dokumentasi dari } \\
\text { berbagai sumber }\end{array}$ & Wawancara dan observasi & $\begin{array}{l}\text { Wawancara mendalam dengan } \\
\text { para informan, observasi } \\
\text { partisipatif, dan } \\
\text { dokumentasi }\end{array}$ \\
\hline $\begin{array}{l}\text { Perbedaan dan } \\
\text { Persamaan } \\
\text { dengan } \\
\text { Penelitian }\end{array}$ & $\begin{array}{l}\text { Perbedaan dengan peneliti } \\
\text { adalah dari objek yang diteliti } \\
\text { dan penggunaan teori yang } \\
\text { berbeda. }\end{array}$ & \begin{tabular}{lcr}
\multicolumn{3}{l}{ Perbedaan dengan peneliti } \\
adalah dari objek dan \\
sasaran & informan yang \\
diteliti. & \multicolumn{2}{c}{ Sedangkan }
\end{tabular} & $\begin{array}{l}\text { Perbedaan dengan peneliti } \\
\text { adalah dari objek yang diteliti } \\
\text { dan penggunaan teori yang } \\
\text { berbeda. }\end{array}$ \\
\hline
\end{tabular}

Fokus penelitian ini adalah perempuan muslim yang menikah dengan Warga Negara Asing (WNA).

Untuk menemukan dan menjelaskan motif, makna dan pengalaman perempuan muslim Indonesia sebagai pelaku perkawinan campuran. 


\begin{tabular}{llllll}
\hline Terdahulu & persamaanna adalah sama- & persamaannya adalah sama- & persamaannya adalah sama-sama \\
& sama meneliti tentang & sama meneliti tentang & meneliti tentang konstruksi \\
& konstruksi makna dengan & konstruksi makna dengan makna dengan pendekatan yang \\
& pendekatan yang sama yaitu pendekatan yang sama yaitu sama yaitu kualitatif dengan \\
& kualitatif dengan metode & kualitatif dengan metode & metode fenomenologi. \\
& fenomenologi. & & fenomenologi. & & \\
\end{tabular}

Sumber: diolah dari berbagai sumber.

Tabel 2

Fokus Metode Penelitian

\begin{tabular}{ll}
\hline \multicolumn{1}{c}{ Metode Penelitian } & \multicolumn{2}{c}{ Keterangan } \\
\hline Pendekatan Penelitian & $\begin{array}{l}\text { Pendekatan yang digunakan dalam penelitian ini adalah } \\
\text { pendekatan kualitatif atau juga disebut sebagai metode } \\
\text { naturalistik dengan kondisi alamiah (natural setting). }\end{array}$
\end{tabular}

Paradigma Penelitian

Subjek Penelitian

Teknik Penentuan Informan

Pemilihan Informan

Jumlah Informan

Teknik Pengumpulan Data
Paradigma penelitian ini adalah konstruktivis yang mengkaji pemahaman mengenai konstruksi makna perkawinan campuran bagi perempuan muslim Indonesia dengan WNA.

Subjek pada penelitian ini adalah perempuan muslim Indonesia yang menikah dengan WNA dengan batasan usia 30-40 tahun.

Teknik penentuan informan ini dengan teknik purposive sampling yaitu peneliti sudah menentukan sejumlah informan sesuai dengan tujuan yang ingin diperoleh.

Pemilihan informan didasarkan kepada informan yang mampu menggambarkan kembali fenomenanya yang telah dialaminya terutama dalam sifat alamiah dan maknanya, bersedia untuk terlibat dalam kegiatan penelitian yang membutuhkan waktu yang lama, serta bersedia untuk diwawancara dan direkam aktivitasnya selama wawancara atau selama penelitian berlangsung.

Jumlah informan yang digunakan sebanyak 8 (delapan) orang.

Teknik pengumpulan data yang digunakan adalah observasi partisipan, wawancara mendalam, dokumentasi, dan studi kepustakaan.

Sumber: Hasil penelitian berdasarkan data Informan.

bertujuan untuk menggali kesadaran terdalam para subjek mengenai pengalaman beserta maknanya. Sedangkan pengertian fenomena dalam Studi Fenomenologi sendiri adalah pengalaman atau peristiwa yang masuk ke dalam kesadaran subjek. Wawasan utama fenomenologi adalah pengertian dan penjelasan dari suatu realitas harus dibuahkan dari gejala realitas itu sendiri (Aminuddin, 1990).

Teori fenomenologi memberikan konstribusi dalam memaknai sebuah realitas yang berkenaan dengan fenomena konstruksi makna perkawinan campuran bagi perempuan muslim Indonesia. Hal ini, bisa mempelajari struktur tentang kehidupan dari setiap pelaku yang melakukan perkawinan dengan WNA dari sudut pandang para informan yaitu, makna, motif dan pengalaman.

\section{METODE PENELITIAN}

Penelitian ini menggunakan metode fenomenologi, yang mencerminkan sebuah pengalaman kehidupan seseorang dalam hal ini para pelaku perkawinan campuran perempuan muslim Indonesia. Dalam fenomenologi yang dipelajari adalah dunia 
Tabel 3

Penjelasan Tentang Motif Because (Karena) dan Motif In Order To (Untuk)

\begin{tabular}{cc}
\hline Penjelasan Motif & Kategori \\
\hline $\begin{array}{l}\text { Motif Trauma. Jenis motif ini ada rasa ketraumaan dari informan yang } \\
\text { menikah dengan orang Indonesia (kegagalan berumah tangga dengan }\end{array}$ & Because
\end{tabular}
WNI).

Motif Ketertarikan. Jenis motif ini timbulnya rasa cinta dan sayang Because dikarenakan adanya hubungan yang sudah lama terjalin selama 9 tahun. Perbedaan budaya dan bahasa membuat informan untuk lebih jauh saling mempelajari satu sama lainnya.

Motif Romantis. Bahwa motif menikah dengan WNA memiliki suasana Because yang berbeda, adanya rasa romantik, respek, saling mendukung kepada perempuan dibandingkan dengan pria WNI.

Motif Impian. Motif ini menjadi impian bagi salah satu informan untuk menikah dengan WNA sejak usia remaja. Hal ini menjadikan rasa bangga dan impian menjadi tercapai.

Motif Beribadah. Motif menikah dengan WNA sebagai bentuk ibadah, hal ini terjadi secara alami WNA menjadi mualaf.

Motif Memperbaiki Keturunan. Motif ini bahwa perempuan muslim Indonesia ingin menghasilkan keturunan bule, tinggi, berkulit putih, dan berhidung mancung dan menarik.

Sumber: Hasil Penelitian

kehidupan seperti yang biasa manusia alami, tanpa proses berfikir, tanpa konsep, teori, dan kategori (Neuman, 2000). Menurut Schutz tugas fenomenologi adalah menghubungkan antara pengetahuan ilmiah dengan pengalaman sehari-hari dan dari kegiatan di mana pengalaman dan pengetahuan itu berasal. Menurutnya tindakan sosial mendasarkan diri pada pengalaman, makna dan kesadaran (Garna, 2009). Fokus metode penelitian ini secara rinci bisa di lihat pada tabel 2 .

\section{HASIL PENELITIAN DAN PEMBAHASAN}

\section{Motif Perkawinan Campuran}

Berdasarkan hasil yang dilakukan, peneliti mendapatkan hasil yang beragam mengenai motif dari perempuan muslim Indonesia. Motif yang dihasilkan terbagi dalam dua kategori jenis motif yaitu motif in order to terdiri dari motif impian, motif untuk beribadah, motif memperbaiki keturunan dan motif because terdiri dari motif trauma, motif ketertarikan, dan motif romantis. Motif untuk (in order to motives), artinya bahwa sesuatu merupakan tujuan yang digambarkan sebagai maksud, rencana, harapan, minat, dan sebagainya yang berorientasi pada masa depan. Dengan kata lain, jenis motif ini lebih kepada alasan seseorang melakukan tindakan sebagai usahanya menciptakan situasi dan kondisi yang diharapkan dimasa yang akan datang atau harapan di masa yang akan datang. Motif karena (because motives), artinya sesuatu merujuk pada pengalaman masa lalu individu, karena itu berorientasi pada masa lalu, yaitu aktor atau seseorang merujuk pada beberapa faktor yang berkaitan dengan pengalaman masa lalu yang dilakukan oleh informan. Penjelasan beberapa motif because dan motif in order to dapat dilihat pada tabel 3 .

\section{Pengalaman Perkawinan Campuran}

Pengalaman menarik, menyenangkan atau bahkan pengalaman yang kurang baik pastinya akan selalu dialami oleh seseorang, terlebih ketika melibatkan kehidupan orang lain baik dalam lingkungan keluarga, sekolah, lingkungan kerja, ataupun di lingkungan masyarakat. Hal itu, menuntut dan saling menciptakan 
Tabel 4

Penjelasan Tentang Pengalaman Perkawinan Campuran dengan WNA

Kategori Pengalaman

Pengalaman Berbeda

Budaya dan Kebiasaan

\section{Pengalaman Adaptasi Multicultural}

\section{Terbuka/Open Mind}

Pengalaman Kehidupan Menjadi Lebih Berwarna

\section{Pengalaman Lebih Romantis}

\section{Pengalaman Berbeda Selera} Makanan

\section{Proses Menikah Merepotkan} dan Menghabiskan Biaya

\section{Penjelasan Tentang Pengalaman}

Meskipun berbeda budaya dan kebiasaan tidak menghilangkan rasa kebersamaan dalam menjalankan kehidupan rumah tangga dengan WNA, senantiasa menciptakan keharmonisan dan keterpaduan.

Beradaptasi dengan multicultural yang berbeda tentunya membutuhkan waktu yang sangat panjang. Hal ini menuntut kepada kedua belah pihak untuk saling mengerti akan adanya budaya yang berbeda.

Dalam hal ini, perkawinan campuran dengan WNA lebih to the point dibandingkan dengan karakteristik WNI. Keharmonisan bagi perkawinan campuran menjadi sebuah kunci utama dalam membuka komunikasi.

Perkawinan campuran dengan WNA, tentunya dekat sekali dengan segala perbedaan yang dimiliki. Tetapi tidak selamanya perbedaan itu menjadi sebuah masalah, namun dengan adanya perbedaan dapat saling melengkapi dan menjadikan sesuatu menjadi lebih berwarna dan indah.

Pernikahan dengan WNA dirasakan lebih romantis dan setia meskipun berbeda budaya.

Pastinya perkawinan campuran dengan melibatkan dua negara yang berbeda, memiliki ciri atau selera dari masing-masing negara dan saling beradaptasi/menyesuaikan dan berbeda rasa.

Proses perkawinan campuran membutuhkan proses, karena melibatkan dua negara dan aturan yang berbeda. Selain itu, membutuhkan biaya dan waktu yang tidak sedikit dikeluarkan.

Sumber: Hasil Penelitian

kesesuaian dan kecocokan karena masingmasing orang pasti memiliki latar belakang yang berbeda. Namun, pengalaman pasti akan terus bertambah bagi setiap orang selama seseorang hidup dan berinteraksi dengan orang lain. Terlebih lagi ketika dua orang yang baru saling mengenal berasal dari negara yang berbeda. Dalam hal perkawinan campuran perempuan muslim Indonesia, banyak perbedaan dari segi kebiasaan, budaya, aturan-aturan, pola pikir, dan bahasa. Pengalaman pernikahan yang dibahas pada penelitian ini yaitu pengalaman para informan selama menikah dengan WNA.

\section{Makna Perkawinan Campuran}

Pemaknaan berkaitan dengan

persepsi. Persepsi adalah pengalaman tentang objek, peristiwa atau hubungan yang diperoleh dari panca indra. Makna adalah hubungan antara lambang bunyi dengan acuannya. Makna merupakan bentuk respons dari stimulus yang diperoleh pemeran dalam sosialisasi. Makna yang dihasilkan dari wawancara dengan para informan dapat dilihat pada tabel 5.

Berdasarkan hasil penelitian yang telah dijelaskan, maka dapat dilihat secara keseluruhan rangkaian penelitian ke dalam makna perkawinan campuran hingga konstruksi makna perkawinan campuran bagi perempuan Indonesia yang menikah dengan WNA. Pembahasan juga merupakan bentuk bagan satu kerangka konseptual (gambar 1).

\section{Pembahasan}

Pada bagian ini, penulis akan menguraikan menjadi sebuah pembahasan dari motif perkawinan campuran, pengalaman dalam perkawinan campuran,interpretasi peneliti tentang hasil penelitian dengan analisis terkait teori dan konsep yang telah dikaji. 
Tabel 5

Penjelasan Tentang Makna Perkawinan Campuran dengan WNA

Kategori Makna Penjelasan Tentang Makna

Menarik dan bahagia
$\begin{aligned} & \text { Menghargai dan saling } \\ & \text { pengertian }\end{aligned}$

Perkawinan campuran dimaknai sesuatu hal yang menarik dan menantang (unik). Pernikahan campuran memberikan makna baik secara pengetahuan dan wawasan khususnya tentang budaya yang semakin bertambah.

\author{
pengertian
}

Perkawinan yang indah

\section{Penggabungan dua budaya}

\author{
Kompleks, butuh \\ kesabaran dan \\ pengertian
}

\author{
Menyesuaikan \\ perbedaan
}

Pernikahan yang dilegalkan
Perkawinan campuran dimaknai sebagai perkawinan yang memiliki banyak perbedaan dibandingkan perkawinan dengan WNI. Sehingga dalam sebuah perkawinan campuran dibutuhkan saling menghargai perbedaan yang ada dan berusaha untuk saling pengertian satu sama lain. Dalam memaknai perkawinan campuran, sebelumnya seseorang telah mengalami secara langsung bagaimana pengalaman yang dialami sebagai orang yang melakukan perkawinan campuran tersebut. Setelah mengalami, seseorang baru bisa memaknai perkawinan campuran.

Perkawinan campuran dimaknai sebagai perkawinan yang indah menurut informan kelima yaitu IR, karena dalam perkawinannya sering dibumbui pengalaman-pengalaman baru.

Perkawinan campuran terdiri dari dua negara, otomatis dua negara yang berbeda akan memiliki kebudayaan yang berbeda pula. Perkawinan campuran dimaknai sebagai penggabungan dua budaya, karena perbedaan negara berarti berbeda budaya dan kebiasaan.

Perkawinan campuran lebih "kompleks" dibanding perkawinan dengan WNI. Dibutuhkan kesabaran dan pengertian lebih untuk menjalani dan mempertahankannya. Apalagi perkawinan campuran dilakukan oleh dua orang yang awalnya berbeda keyakinan

Perkawinan didasari perbedaan pola hidup dan karakter sehingga harus menyesuaikan diri satu sama lain.

Perkawinan campuran dimaknai sebagai perkawinan yang berbeda negara yang dilegalkan baik oleh hukum Indonesia ataupun hukum negara pasangan.

Sumber: Hasil Penelitian.

Motif 'untuk' (in order to motives), artinya bahwa sesuatu merupakan tujuan yang digambarkan sebagai maksud, rencana, harapan, minat, dan sebagainya yang berorientasi pada masa depan. Dengan kata lain, jenis motif ini lebih kepada alasan seseorang melakukan tindakan sebagai usahanya menciptakan situasi dan kondisi yang diharapkan di masa yang akan datang atau harapan di masa yang akan datang. Masa depan atau mendatang di sini adalah informan membutuhkan perkawinannya untuk pemenuhan kebutuhan dari dalam dirinya ataupun pemenuhan kebutuhan perkawinannya untuk masa depan lebih baik.
Motif yang termasuk jenis motif "in order to" adalah: motif impian, motif untuk beribadah, motif perbaiki keturunan.

Motif impian menikah dengan WNA adalah salah satu alasan bagi RH melakukan perkawinan campuran. Motif ini termasuk dalam kategori "in order to" karena ketika ia memiliki impian menikah dengan WNA adanya sebuah keinginan atau harapan dan tujuan yang ingin dicapai oleh $\mathrm{RH}$ dalam pernikahannya kelak. Sehingga impian menikah dengan WNA tergolong pada jenis motif "in order to" karena berorientasi pada masa depan. Motif beribadah adalah alasan menikah dengan WNA yang diakui oleh AA karena perkawinannya dijadikannya sebagai salah satu bentuk ibadah kepada Tuhan, Ia memiliki tujuan jelas bahwa ia 
menikah adalah untuk melakukan salah satu perintah agama dalam beribadah kepada Tuhan. Tujuan yang dimiliki AA tersebut tergolong pada jenis motif "in order to". Selanjutnya motif memperbaiki keturunan adalah alasan RA menikah dengan WNA. Ia memiliki tujuan untuk masa depannya yaitu menghasilkan keturunan dengan fisik yang sesuai dengan tipe fisik bule. Memerbaiki keturunan termasuk pada sebuah tujuan/harapan yang ingin dicapai untuk masa depan setelah menikah. Sehingga memperbaiki keturunan termasuk pada jenis motif "in order to".

Motif 'karena' (because motives), artinya sesuatu merujuk pada pengalaman masa lalu individu, karena itu berorientasi pada masa lalu, yaitu aktor atau seseorang merujuk pada beberapa faktor yang

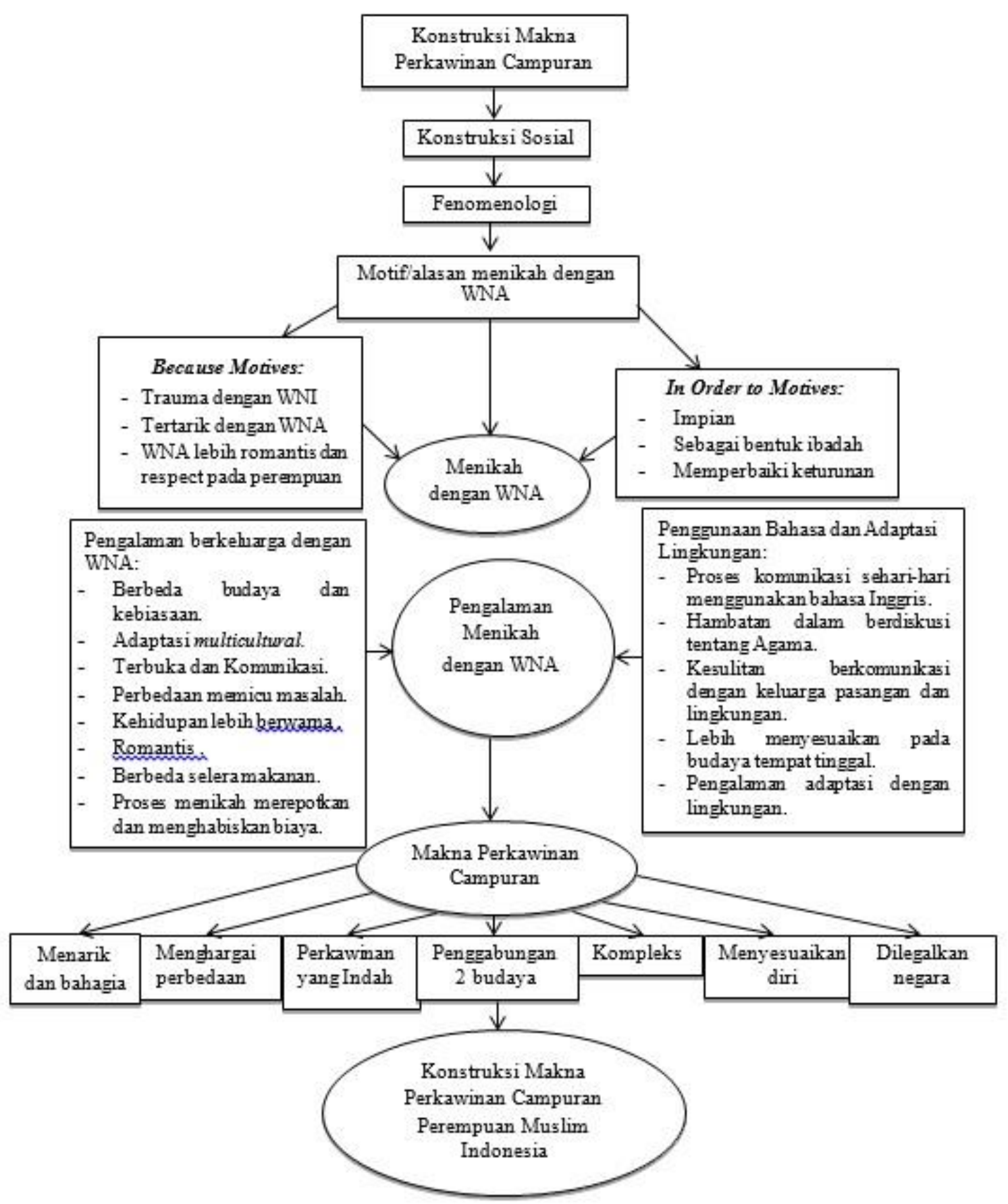

Gambar 1. Kerangka Konseptual Model Konstruksi Makna Perkawinan Campuran Bagi Perempuan Muslim Indonesia yang Menikah Dengan Warga Negara Asing (WNA) 
berkaitan dengan pengalaman masa lalu yang dilakukan oleh informan. Termasuk pada jenis motif because adalah motif trauma, motif ketertarikan, dan motif romantis.

Motif trauma adalah salah satu alasan DH menikah dengan WNA. Sebelumnya ia pernah mengalami kegagalan dengan WNI dan berakhir perceraian, sehingga ia merasa trauma dengan WNI dan ingin mencoba menjalin hubungan dengan WNA, akhirnya ia pun memutuskan menikah dengan WNA. Sehingga ia menikah dengan WNA dengan alasan ada pengalaman yang tidak baik dengan pria WNI. Pengalaman berarti berorientasi pada masa lalu sehingga motif ini termasuk pada jenis "because". Tertarik pada sosok WNA dialami oleh beberapa informan yaitu RH, MY, IH, CA dan RA. Tertarik dari segi fisik, cara berbicara, agama dan juga ketertarikan untuk mempelajari budaya WNA. Sehingga mereka menikah dengan WNA atas dasar ketertarikannya pada WNA termasuk pada jenis motif because yakni berdasarkan pengalamannya mengetahui dan mengenal sosok WNA. Motif DN menikah dengan WNA adalah dari pengalamannya berhubungan dengan WNI dan WNA, ia merasa pria WNA lebih romantis dan respect terhadap perempuan. Sehingga ia memutuskan untuk menikah dengan WNA. Alasannya tersebut termasuk pada jenis motif "because" karena berdasarkan pengalaman yang dialami DA menjalin hubungan dengan WNA.

Setelah mengetahui motif dan melakukan perkawinan campuran, mulai terjadilah pengalaman dari para pelaku perkawinan campuran dalam menjalin kehidupan berkeluarga dengan WNA, sesuai dengan pengalaman para informan. Pengalaman pada dasarnya melalui suatu proses yaitu rangsangan dari luar seperti cahaya untuk mata, bunyi untuk telinga, dan bau untuk hidung melalui alat-alat pancaindera diteruskan ke pusat-pusat tertentu di dalam otak yang lalumenafsirkan sebuah pengamatan. Seseorang mengamati sesuatu karena ada minat perhatian yang mengadakan seleksi di antara semua rangsangan yang terdapat di lingkungan seseorang untuk diamati atau ditafsirkan, kecuali dikerahkan minat perhatian seseorang dengan khusus untuk menafsirkan semuanya. Minat perhatian itu ditentukan oleh struktur kebutuhan atau motif yang terdapat pada seseorang. Jadi, sebenarnya motif-motif seseorang, melalui minat dan perhatian seseorang, memunyai peranan besar dalam menentukan apa yang dilihat, dengar, dan amati di lingkungan seseorang (Gerungan, 2010).

Pengalaman menarik, menyenangkan, atau bahkan pengalaman yang kurang baik pastinya akan selalu dialami oleh seseorang, terlebih ketika melibatkan kehidupan orang lain baik dalam lingkungan keluarga, sekolah, lingkungan kerja ataupun di lingkungan masyarakat. Oleh karena itu, seseorang dituntut untuk menciptakan sebuah kesesuaian dan kecocokan karena masing-masing orang pasti memiliki latar belakang yang berbeda. Namun, pengalaman pasti akan terus dihadapi oleh setiap orang selama seseorang hidup dan berinteraksi dengan orang lain. Terlebih lagi ketika dua orang yang baru saling mengenal ini berasal dari negara yang berbeda. Jelas sekali banyak perbedaan dari segi kebiasaan, aturan-aturan, pola pikir, bahasa, dan sebagainya yang menciptakan pengalaman-pengalaman baru. Pengalaman pernikahan yang dibahas pada penelitian ini yaitu pengalaman para informan selama menikah dengan WNA.

Dari paparan pembahasan yang telah dijelaskan, maka pendekatan fenomenologi Schutz dalam Kuswarno (2009) adalah melihat manusia dari pengalaman subjektifnya. Dalam konteks fenomenologis pula, para informan yakni perempuan muslim Indonesia adalah aktor yang melakukan tindakan sosial (menikah dengan WNA) bersama aktor lainnya sehingga memiliki kesamaan dan kebersamaan dalam ikatan makna perkawinan campuran. Hal tersebut sesuai dengan pendapat Schutz dalam Sobur (2009), yaitu para informan memiliki salah satu atau kedua-duanya dari 
kedua jenis motif yaitu motif "untuk" dan "karena".

\section{PENUTUP}

\section{Simpulan}

Fenomena perkawinan campuran pada perempuan Indonesia yang beragama Islam memiliki motif yang terbagi dalam dua kategori yaitu motif "because" atau motif karena yang terdiri dari motif trauma dan motif ketertarikan serta kategori motif "in order to" atau motif untuk yang terdiri dari motif impian, motif beribadah, dan motif memperbaiki keturunan.

Pengalaman yang didapat dari perempuan muslim Indonesia selama menikah dengan WNA adalah pengalaman saling menyesuaikan budaya, pengalaman beradaptasi multikultur, membiasakan sikap terbuka dan komunikasi, romantis, perbedaan selera makanan, merepotkan dan menghabiskan biaya, kesulitan beradaptasi dengan lingkungan pasangan, dan lebih menyesuaikan pada budaya tempat tinggal.

Makna dari perkawinan campuran bagi perempuan muslim Indonesia adalah menarik, bahagia, penggabungan dua budaya, menghargai perbedaan dan saling pengertian, kompleks, indah, dan ribet. Kesimpulan konstruksi makna perkawinan campuran adalah perkawinan yang memiliki banyak sekali perbedaan, perkawinan yang kompleks, hingga dibutuhkan saling pengertian dan kesabaran yang lebih, namun dengan perbedaan yang beragam tersebut justru kehidupan menjadi lebih menarik dan berwarna.

Kontruksi makna yang terbentuk adalah bahwa perkawinan campuran adalah perkawinan yang menarik, indah dan penuh tantangan dalam menghadapi perbedaanperbedaan yang ada dari sisi kebudayaan, kebiasaan, pola pikir, bahkan ketika memiliki pasangan seorang mualaf yang berbeda pengetahuan tentang agama, maka akan semakin banyak pula tantangan dalam menciptakan sebuah kecocokan satu sama lain dalam menjalankan kehidupan keluarga.

\section{Saran}

Saran secara teoretis bahwa penelitian yang sifatnya alamiah atau subjektivitas dapat dibedah dengan menggunakan teoriteori komunikasi yang sesuai dengan fenomena yang diteliti. Bahwa dalam penelitian kualitatif memberikan kebermaknaan tersendiri sehingga konstruksi makna tentang perkawinan campuran ini bisa dikaji dari aspek teori komunikasi yang lainnya.

Diharapkan untuk perempuan Indonesia yang sedang menjalin hubungan dengan Warga Negara Asing dan ingin menuju ke jenjang pernikahan, sebaiknya perkenalan tidak dilakukan secara singkat, sebaiknya saling mengenal karakter satu sama lain dan dapat saling mengenal pada keluarga pasangan. Dengan banyaknya perbedaan yang akan dihadapi setelah menikah, maka dibutuhkan saling pengertian dan saling menghargai kebudayaan pasangan. Hal yang terpenting dari perkawinan campuran adalah menjadikan segala sesuatunya berlandaskan atas aturan agama.

\section{DAFTAR PUSTAKA}

Aminuddin. (1990). Pengembangan Penelitian Kualitatif dalam Bidang Bahasa dan Sastra. Malang: Yayasan Asih, Asah, Asuh.

Basrowi and Sukidin. (2002). Metode Penelitian Perspektif Mikro: Grounded Theory, Fenomenologi, Etnometodologi, Etnografi, Dramaturgi, Interaksi Simbolik, Hermeneutik, Konstruksi Sosial, Analisis Wacana, dan Metodologi Refleksi. Surabaya: Insan Cendekia.

Garna, Y. K. (2009). Metoda Penelitian Kualitatif. Bandung: Judistira Foundation dan Primaco Akademika Bandung.

Gerungan, W. A. (2010). Psikologi Sosial. Bandung: PT. Refika Aditama.

Kuswarno, E. (2009). Metode Penelitian Komunikasi, Fenomenologi, Konsepsi, 
Pedoman, dan Contoh Penelitiannya. Republik Indonesia. (1974). Undang-Undang Bandung: Widya Padjadjaran.

Neuman, L. W. (2000). Social Research Methods: Quantitative and Qualitative Approaches. 4th ed. Boston: Allyn and Barcon.

Poloma, M. M. (2000). Sosiologi Kontemporer. Jakarta: PT. Raja Grafindo Persada.

No. 1 Tahun 1974 tentang Perkawinan. Republik Indonesia.

Sobur, A. (2009). Psikologi Umum. Bandung: Pustaka Setia.

Suparno, P. (1997). Filsafat Konstruktivisme dalam Pendidikan. Yogyakarta: Kanisius. 